\title{
KARAKTERISTIK SISWA SEBAGAI PIJAKAN DALAM PENELITIAN DAN METODE PEMBELAJARAN
}

\author{
C. Asri Budiningsih \\ FIP Universitas Negeri Yogyakarta (e-mail: asri_budi@yahoo.co.id; \\ HP. 081328851883)
}

\begin{abstract}
Learner Characteristics as a Basis for Teaching Method and Research on Instruction. The instructional technology focuses its analysis on the improvement of the instructional quality on the basis of instructional strategies or instructional method variables. Instructional methods variables are classified into three main categories: (1) organizational strategy, (2) delivery strategy, and (3) management strategy. The variables which greatly influence the utilization of instructtional methods are the instructional condition variables, classified into three categories: (1) objectives and characteristics of a field of study, (2) constraints and characteristics of a field of study, and (3) learner characteristics. The learner characteristics are students' personal quality, such as their intelligence, prior knowledge, cognitive styles, learning styles, motivation, and socio-cultural factors, which greatly influence the process and result of the study. Learner characteristics will determine the selection of the management strategy, which is also related to the method to organize the learning process. The learner characteristics have to be accepted as a given condition and utilized as a basis for research on instruction.
\end{abstract}

Keywords: instructional variables, learner characteristics

\section{PENDAHULUAN}

Banyak faktor penyebab kualitas pendidikan rendah, di antaranya kegiatan pembelajaran yangkurang tanggap terhadap kemajemukan individu dan lingkungan tempat siswa berada. Pembelajaran demikian kurang bermanfaat bagi siswa. Agar pembelajaran bermakna, perlu dirancang dan dikembangkan berdasarkan pada kondisi siswa sebagai subjek belajar dan komunitas budaya tempat siswa tinggal. Siswa adalah manusia yang memiliki sejarah, makhluk dengan ciri keunikannya (individuallitas). Pema- haman akan subjek belajar harus dimiliki oleh guru atau tenaga kependidikan lainnya untuk dijadikan pijakan dalam mengembangkan teori ataupun praksis-praksis pendidikan dan pembelajaran.

Sistem pendidikan klasikal formal dan masal yang selama ini dilakukan akan menghasilkan proses dan hasil pendidikan yang dangkal dan tidak mendasar. Siswa tidak terbiasa terlibat aktif dalam proses belajar di kelas, mereka pasif. Akibatnya, pemahaman pengetahuan mereka minim, belajar menjadi tidak bermakna, tidak kon- 
tekstual, kurang menggairahkan dan kurang menyentuh kehidupan sosiokultural siswa.

Banyak upaya peningkatan kualitas pembelajaran telah lama dilakukan oleh para ilmuwan pembelajaran. Mereka mengklasifikasikan variabelvariabel yang menjadi perhatian, terutama bila dikaitkan dengan kegiatan dalam mengembangkan teori-teori dan prinsip-prinsip pembelajaran. Di antara para ilmuwan tersebut adalah Reigeluth dan Merrill. Mereka membuat klasifikasi ke dalam tiga variabel pembelajaran utama, yaitu: (1) kondisi pembelajaran; (2) metode pembelajaran; dan (3) hasil pembelajaran (Reigeluth, 1983:29; Degeng, 1989:18).

Kondisi pembelajaran adalah faktor yang mempengaruhi efek metode dalam meningkatkan hasil pembelajaran. Kondisi pembelajaran berinteraksi dengan metode pembelajaran, dan hakikatnya tidak dapat dimanipulasi. Metode pembelajaran didefinisikan sebagai cara-cara yang berbeda untuk mencapai hasil pembelajaran yang berbeda di bawah kondisi pembelajaran yang berbeda. Pada dasarnya, cara ini dapat dimanipulasi oleh guru atau perancang pembelajaran. Bila dalam suatu situasi, metode pembelajaran tidak dapat dimanipulasi, ia berubah menjadi kondisi pembelajaran. Sebaliknya, jika suatu kondisi pembelajaran dalam suatu situasi dapat dimanipulasi, ia berubah menjadi metode pembelajaran. Hasil pembelajaran mencakup semua efek yang dapat dijadikan sebagai indikator tentang nilai dari penggunaan metode pembelajaran di bawah kondisipembelajaran yang berbeda. Hasil pembelajaran dapat berupahasil nyata (actual outcomes) dan hasil yang diinginkan (desired outcomes).

Masing-masing variabel pembelajaran di atas diidentifikasi ke dalam suatu model atau teori pembelajaran sebagai berikut. Variabel kondisi pembelajaran dikategorikan menjadi tiga subvariabel, yaitu tujuan pembelajaran, kendala dan karakteristik bidang studi, dan karakteristik siswa. Variabelmetode dikategorikan menjadi tiga subvariabel, yaitu strategi pengorganisasian materi (mikro dan makro), strategi penyampaian isi, dan strategi pengelolaan pembelajaran. Variabel hasil pembelajaran, dikategorikan menjadi tiga subvariabel, yaitu keefektifan, efisiensi, dan daya tarik pembelajaran. Variabel-variabel pembelajaran tersebut dapat dilihat pada Diagram 1.

Klasifikasi variabel-variabel pembelajaran dapat dijadikan pedoman dalam menformulasikan langkah-langkah perencanaan pembelajaran. Langkah-langkah tersebut adalah: (1) analisis tujuan dan karakteristik bidang studi; (2) analisis sumber belajar (kendala); (3) analisis karakteristik siswa; (4) menetapkan tujuan belajar dan isi pembelajaran; (5) menetapkan strategi pengorganisasian isi pembelajaran; (6) menetapkan strategi penyampaian isi pembelajaran; (7) menetapkan strategi pengelolaan pembelajaran; (8) mengembangkan prosedur pengukuran hasil pembelajaran (Degeng, 1991). 


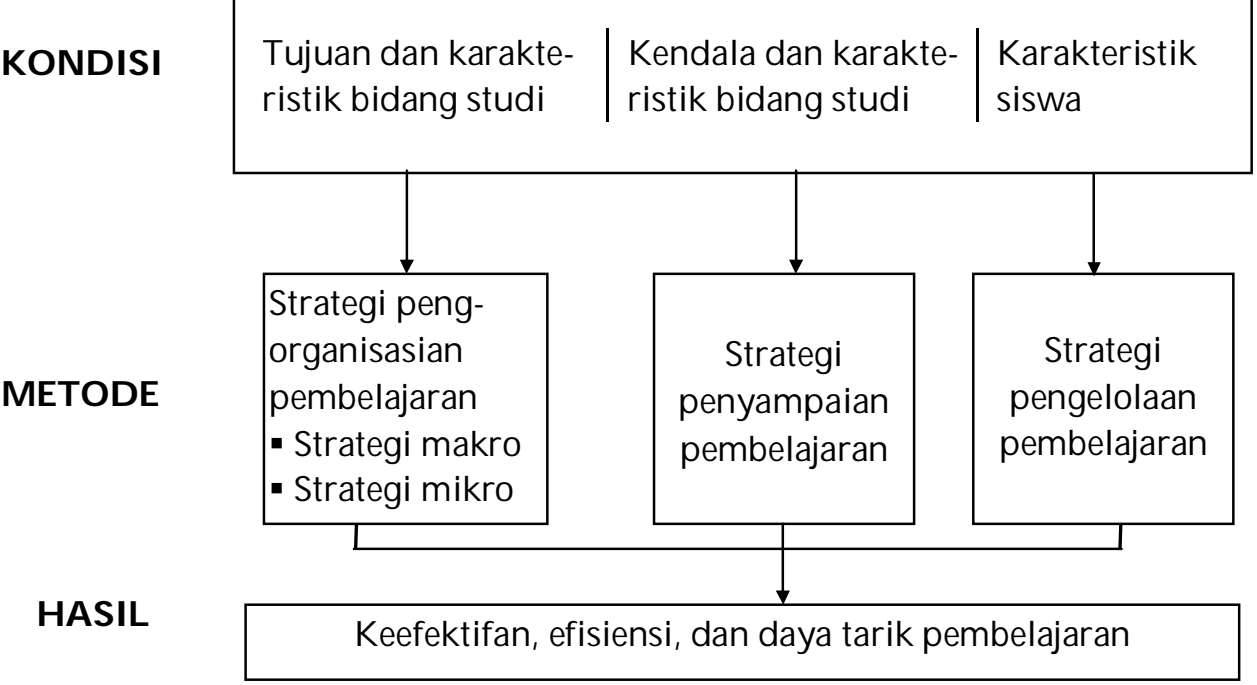

Diagram 1: Taksonomi Variabel Pembelajaran (Reigeluth, 1983; Degeng, 1989)

Prinsip-prinsip dan teori-teori pembelajaran di atas banyak dikembangkan berdasarkan pengalaman, intuisi, dan logika (Degeng, 1991). Oleh karena itu, diperlukan adanya validasi dan dukungan empirik untuk menetapkan kesahihannya. Hal ini dapat dilakukan melalui penelitian-penelitian ilmiah. Peluang terjadinya interaksi antara variabel metode dan variabel kondisi amat besar dalam menentukan variabel hasil pembelajaran. Oleh karena itu, diperlukan identifikasi variabel-variabel metode mana yang berinteraksi dengan variabel kondisi dalam menentukan hasil pembelajaran yang konsisten.

Pemetaan variabel-variabel pembelajaran tersebut amat membantu guru dan peneliti dalam mengidentifikasi dan menetapkan hubunganhubungan antara variabel pembelajaran mana yang perlu diuji. Hal ini dimaksudkan untuk memberikan pijakan yang sama kepada peneliti- peneliti di bidang ilmu pembelajaran dan teknologi pembelajaran sehingga temuan-temuannya dapat dengan mudah diintegrasikan dengan temuantemuan penelitian sebelumnya. Dengan cara demikian, upaya untuk menciptakan landasan pengetahuan (ilmiah) perbaikan kualitas pembelajaran dapat diwujudkan.

\section{KARAKTERISTIK SISWA DALAM PENELITIAN PEMBELAJARAN}

Menurut Vygotsky agar pembelajaran bermakna, perlu dirancang dan dikembangkan berpijak pada kondisi siswa sebagai subjek belajar serta komunitas sosial-kultural tempat siswa tinggal (Moll, 1994). Menurut Waidl (Admadi \& Setiyaningsih, 2004), hal penting yang harus dipahami yang berkaitan dengan siswa atau peserta belajar sebagai individu bahwa siswa adalah manusia yang memiliki sejarah, makhluk dengan ciri keunikan (individualitas), selalu 
membutuhkan sosialisasi di antara mereka, memiliki hasrat untuk melakukan hubungan dengan alam sekitar, dan dengan kebebasannya mengolah pikir dan rasa akan pertemuannya dengan Yang Transendental. Pemahaman terhadap siswa sebagai subjek belajar inilah yang harus dijadikan pijakan dalam mengembangkan teori-teori maupun praksis-praksis pendidikan.

Penelitian tentang karakteristik siswa sebagai pijakan pembelajaran telah banyak dilakukan. Suhardjono (1990) menemukan bahwa perbedaan karakteristik siswa dan pengorganisasian materi pembelajaran berpengaruh terhadap perolehan dan retensi belajar. Penelitian Lusiana (1992) tentang penggunaan strategi penataan isi mata kuliah yang berkaitan dengan gaya kognitif mahasiswa berpengaruh terhadap perolehan belajar. Degeng (1998) dalam penelitiannya yang berjudul Interactive Effects of Instructional Strategies and Learner Characteristics on Learning Effectiveness, Efficiency, and Appeal menyimpulkan adanya interaksi antara strategi pengorganisasian materi pembelajaran dan karakteristik siswa pada keefektifan belajar. Mereka berusaha menguji kesahihan variabel-variabel pembelajaran tersebut, dan menemukan bahwa peluang terjadinya interaksi antara variabel metode (pengorganisasian materi pembelajaran) dan variabel kondisi (karakteristik siswa) pada keefektifan belajar adalah besar. Hal senada juga dibuktikan oleh Anitah (1996) melalui konteks pembelajaran bidang studi yang berbeda.
Pembuktian juga dilakukan oleh para peneliti pada dekade tahun-tahun terakhir ini. Hasil penelitian Triyono $(2008 ; 15)$ menunjukkan adanya interaksi antara strategi pembelajaran yang digunakan dosen dengan karakteristik mahasiswa yang berupa kemampuan analitiknya. Bagi mahasiswa yang memiliki kemampuan analitik tinggi, penggunaan strategi pembelajaran lengkap memberikan hasil ketrampilan pneumatik yang lebih tinggi dibandingkan dengan penggunaan strategi pembelajaran demonstrasi. Sebaliknya, strategi pembelajaran demonstrasi lebih tepat gunakan bagi mahasiswa dengan kemampuan analitik lebih rendah. Kelompok mahasiswa dengan kemampuan analitik lebih rendah memerlukan bimbingan selama proses pembelajaran. Contohcontoh dan petunjuk dosen merupakan panduan yang sangat menolong pada saat mereka bekerja. Berdasarkan temuan ini disarankan agar para dosen dalam menggunakan strategi pembelajaran mempertimbangkan kemampuan analitik mahasiswa agar penguasaan belajar mereka meningkat.

Haryanto (2009; 153-159) dalam penelitiannya yang berjudul Efikasi Diri, Kualitas Pengajaran, Sikap Positif dan Kinerja Akademis Mahasiswa menemukan bukti bahwa semakin tinggi tingkat efikasi diri, semakin tinggi pula kesiapan mahasiswa dalam mempersiapkan dan menjalani proses perkuliahan. Efikasi diri (self efficacy) diartikan sebagai tingkat kesiapan siswa dalam mengorganisasi diri untuk mengikuti proses pembelajaran sehingga 
mencapai kinerja akademis yang diharapkan (Galetto dalam Haryanto, 2009). Temuannya memberikan pemahaman tentang perlunya efikasi diri siswa dalam upaya meningkatkan pencapaian kinerja akademis. Efikasi diri dapat ditingkatkan melalui perencanaan dan tindakan pembelajaran yang dapat meningkatkan kemauan siswa untuk berpestasi.

Dukungan lain datang dari penelitian Indarini (2009:176-177) yang berjudul Peningkatan Aktivitas dan Pemahaman Siswa dalam Pembelajaran Kimia melalui Pendekatan Kontekstual. Penelitian ini menambah bukti bahwa karakteristik siswa yang berkaitan dengan kemampuan awal siswa dalam melakukan dan berpikir merupakan asas dalam pendekatan kontekstual. Paduan keduanya mendorong naluri ingin tahu siswa dan menjadikan pembelajaran merupakan suatu aktivitas yang bermakna bagi dirinya. Callahan (2002) mengemukakan bahwa jika siswa dapat menghubungkan, mengalami, mengaplikasikan, mentransfer pengetahuan yang diterimanya dan dapat bekerjasama dengan baik, pembelajaran melalui pendekatan kontekstual akan memberikan hasil belajar yang lebih terpadu, terintegrasi, efektif, bermakna, dan tahan lama dalam ingatan.

Sementara itu, Paulina Pannen (dalam Padmo, 2003:221) menegaskan bahwa dalam merancang dan melaksanakan pembelajaran, jika dikaitkan dengan karakteristik budaya siswa, hasil belajar siswa akan meningkat. Ia mengatakan bahwa guru dalam melaksanakan tindak belajar harus ber- pijak pada budaya siswa karena latar belakang budaya siswa akan berpengaruh terhadap proses dan hasil belajarnya. Hal ini dibuktikan oleh hasil temuan Djohan (2009) yang menunjukkan bahwa kecerdasan sosial siswa di daerah (Yogyakarta) memiliki rerata lebih tinggi dibandingkan dengan rerata kecerdasan sosial siswa di kota besar (Jakarta). Artinya, guru di dalam memilih strategi pembelajaran harus mempertimbangkan kecerdasan atau kemampuan siswa yang relevan dengan strategi pembelajaran yang digunakan. Misalnya, kecerdasan sosial akan sangat berpengaruh terhadap penggunaan strategi ccooperative learning dan ccollaborative learning dalam pembelajaran.

Pengujian-pengujian suatu hubungan antara variabel sebaiknya diikuti dengan pengujian ulang dengan menggunakan latar (kondisi) yang berbeda, seperti perbedaan karakteristik subjek, bidang studi (materi), dan tujuan pembelajaran. Hal ini diperlukan di samping untuk menguji kesahihan temuan penelitian, juga untuk menguji tingkat konsistensi. Hubungan-hubungan variabel yang sahih dan konsisten inilah yang bermanfaat dijadikan landasan ilmiah ilmu dan teknologi pembelajaran. Temuan-temuan komulatif seperti ini nanti akan sangat berguna dalam melakukan metaanalisis.

Di samping pengubahan variabel kondisi, pengujian ulang suatu temuan penelitian juga dapat dilakukan dengan pengubahan variabel hasil. Metode pembelajaran tertentu biasanya dikembangkan untuk mencapai 
hasil pembelajaran tertentu di bawah kondisi tertentu. Dalam hal ini, pengubahan variabel hasil pembelajaran akan dapat memberikan gambaran keefektifan yang berbeda dari suatu metode pembelajaran. Temuan-temuan seperti ini akan sangat berguna dalam mempreskripsikan metode yang optimal untuk mencapai hasil pembelajaran tertentu. Pencarian ini dapat dilakukan melalui penelitian-penelitian tindakan kelas (PTK).

Penelitian tindakan kelas (PTK) bertujuan untuk melakukan perbaikan-perbaikan terhadap sistem, cara kerja, proses, kompetensi dan isi pembelajaran guna mencapai tujuan yang diharapkan. Beberapa penelitian tindakan kelas yang telah dilakukan membuktikan keampuhan metode pembelajaran tertentu untuk mencapai hasil pembelajaran tertentu di bawah kondisi tertentu. Dewanti (2009: 25) membuktikan bahwa strategi pembelajaran yang digunakan guru jika disesuaikan dengan kebutuhan siswa akan meningkatkan efektivitas belajar siswa. Ia menyarankan, strategi pembelajaran matematika seharusnya mempertimbangkan keadaan siswa dan manfaatnya bagi kehidupan mereka sehari-hari. Berpijak pada karakteristik kebutuhan siswa tersebut, pembelajaran matematika merupakan suatu aktivitas manusia (a human activity), dan harus ditemukan kembali (re-invented), bukan disajikan sebagai sebuah produk siap pakai (ready-made product). Penelitian Siskandar (2009: 183) menambah bukti bahwa faktor internal atau faktor yang datang dari dalam diri siswa sangat berpengaruh terhadap hasil belajarnya. Untuk itu, ia menyarankan agar pembelajaran berpusat pada gaya belajar siswa atau pada bagaimana cara siswa menggunakan pengetahuannya.

Pengujian-pengujian hubungan antara variabel pembelajaran sebaiknya juga diikuti oleh pengujian-pengujian ulang dengan menggunakan latar (kondisi) berbeda yang dapat dilakukan melalui penelitian pengembangan (Research and Development). Beberapa penelitian pengembangan untuk menghasilkan media atau sumber-sumber belajar juga telah dilakukan dan menunjukkan hasil yang konsisten. Penelitian pengembangan multimedia pembelajaran yang dilakukan oleh Rahmadona (2008) yang berpijak pada karakteristik anakusia dini mampu meningkatkan kecerdasan anak yang mengarah pada pembentukan perilaku positif. Demikian juga penelitian pengembangan multimedia pembelajaran Sosiologi bagi siswa-siswa SMA yang dilakukan oleh Suparmi (2010) yang berpijak pada karakteristik siswa juga mampu menghasilkan media yang efektif, efisien, dan dapat meningkatkan daya tarik belajar siswa.

Berdasarkan uraian tentang variabel-variabel pembelajaran diatas, serta melihat kondisi belum optimalnya hasil belajar siswa saat ini, tugas yang diemban para pendidik dan perancang di bidang pembelajaran sangat rumit karena harus berhadapan dengan sejumlah variabel kondisi yang berada di luar kontrolnya. Satu variabel yang sama sekali tidak dapat dimanipulasi oleh guru atau perancang 
pembelajaran adalah karakteristik siswa. Variabel ini mutlak harus dijadikan pijakan dalam memilih dan mengembangkan strategi pembelajaran yang optimal. Upaya apapun yang dipilih dan dilakukan oleh guru dan perancang pembelajaran harus bertumpu pada karakteristik perseorangan siswa sebagai subjek belajar.

Ilmuwan pembelajaran dan teknolog pembelajaran juga menghadapi hal yang serupa dalam mengembangkan prinsip-prinsip pembelajaran. Ia harus menempatkan variabel-variabel kondisional ini, khususnya variabel karakteristik siswa sebagai titik awal dalam mempreskripsikan strategi pembelajaran yang akan digunakan. Bila tidak, maka teori-teori dan prinsip-prinsip pembelajaran yang dikembangkannya sama sekali tidak akan ada gunanya bagi pelaksanaan pembelajaran (Degeng, 1991).

\section{KARAKTERISTIK SISWA SEBAGAI VARIABEL PEMBELAJARAN}

Reigeluth (1983) sebagai seorang ilmuwan pembelajaran, bahkan secara tegas menempatkan karakteristik siswa sebagai satu variabel yang paling berpengaruh dalam pengembangan strategi pengelolaan pembelajaran. Pakar pembelajaran seperti Banathy, Romiszowski, Dick dan Carey, Gagne dan Degeng, menempatkan langkah analisis karakteristik siswa pada posisi yang sangat penting sebelum langkah pemilihan dan pengembangan strategi pembelajaran. Semua ini menunjukkan bahwa model pembelajaran apapun yang dikembangkan atau strategi apapun yang dipilih un- tuk keperluan pembelajaran haruslah berpijak pada karakteristik perseorangan atau kelompok dari siapa yang belajar. Untuk mengembangkan strategi pembelajaran yang optimal, terlebih dahulu guru perlu mengetahui karakteristik siswa sebagai pijakannya.

Karakteristik siswa adalah bagianbagian pengalaman siswa yang berpengaruh pada keefektifan proses belajar (Seels dan Richey, 1994). Penelitian tentang karakteristik siswa bertujuan untuk mendeskripsikan bagian-bagian kepribadian siswa yang perlu diperhati-kan untuk kepentingan rancangan pembelajaran. Ardhana (1999) lebih jelas mengatakan bahwa karakteristik siswa adalah salah satu variabel dalam domain desain pembelajaran yang biasanya didefinisikan sebagai latar belakang pengalaman yang dimiliki oleh siswa termasuk aspek-aspek lain yang ada pada diri mereka seperti kemampuan umum, ekspektasi terhadap pembelajaran, dan ciri-ciri jasmani serta emosional siswa, yang memberikan dampak terhadap keefektifan belajar.

Degeng (1991:6) mengatakan bahwa karakteristik siswaadalah aspekaspek atau kualitas perseorangan siswa yang telah dimilikinya. Menganalisis karakteristik siswa dimaksudkan untuk mengetahui ciri-ciri perseorangan siswa. Hasil dari kegiatan ini akan berupa daftar yang memuat pengelompokkan karakteristik siswa, sebagai pijakan untuk mempreskripsikan metode yang optimal guna mencapai hasil belajar tertentu. 
Karakteristik siswa sebagai salah satu variabel dalam domain desain pembelajaran akan memberikan dampak terhadap keefektifan belajar. Selama ini, teori-teori dan prinsip-prinsip pembelajaran yang dikembangkan di Indonesia lebih banyak berpijak pada karakteristik siswa, tempat teori itu dikembangkan, lebih khusus lagi adalah karakteristik siswa di negaranegara Barat, terutama di Amerika Serikat (Degeng, 1991). Adopsi teoriteori dan prinsip-prinsip pembelajaran oleh perancang pembelajaran di Indonesia sering kali menemui kegagalan. Hal ini dimungkinkan oleh dasar pijakan yang berbeda atau variabel kondisional yang berbeda dengan kondisi tempat pembelajaran dilakukan. Variabel yang berhubungan dengan karakteristik siswa dan budayanya penting dijadikan pijakan pengembangan program pembelajaran di Indonesia.

Bahasan ini dimaksudkan untuk menempatkan konteks masalah kajian penelitian dan praktik-praktik pembelajaran dalam klasifikasi variabel-variabel pembelajaran. Secara jelas, da- pat dikatakan bahwa karakteristik siswa, termasuk dalam variabel kondisi pembelajaran. Sebagai variabel kondisi, berarti karakteristik siswa harus diterima apa adanya dan dijadikan pijakan kerja dalam mengembangkan desain pembelajaran. Klasifikasi variabel-variabel pembelajaran seperti dijelaskan di atas dapat dijadikan pedoman bagi guru dan para perancang atau teknolog pembelajaran dalam memformulasikan langkah-langkah mendesain pembelajaran. Langkahlangkah tersebut adalah: (1) melakukan analisis tujuan dan karakteristik materi pembelajaran; (2) menganalisis sumber-sumber belajar (kendala); (3) melakukan analisis karakteristik siswa; (4) menetapkan tujuan belajar dan isi pembelajaran; (5) menetapkan strategi pengorganisasian isi pembelajaran; (6) menetapkan strategi penyampaian isi pembelajaran; (7) menetapkan strategi pengelolaan pembelajaran; (8) mengembangkan prosedur pengukuran hasil pembelajaran. Kedelapan, langkah ini apabila didiagramkan akan terlihat sebagai berikut.

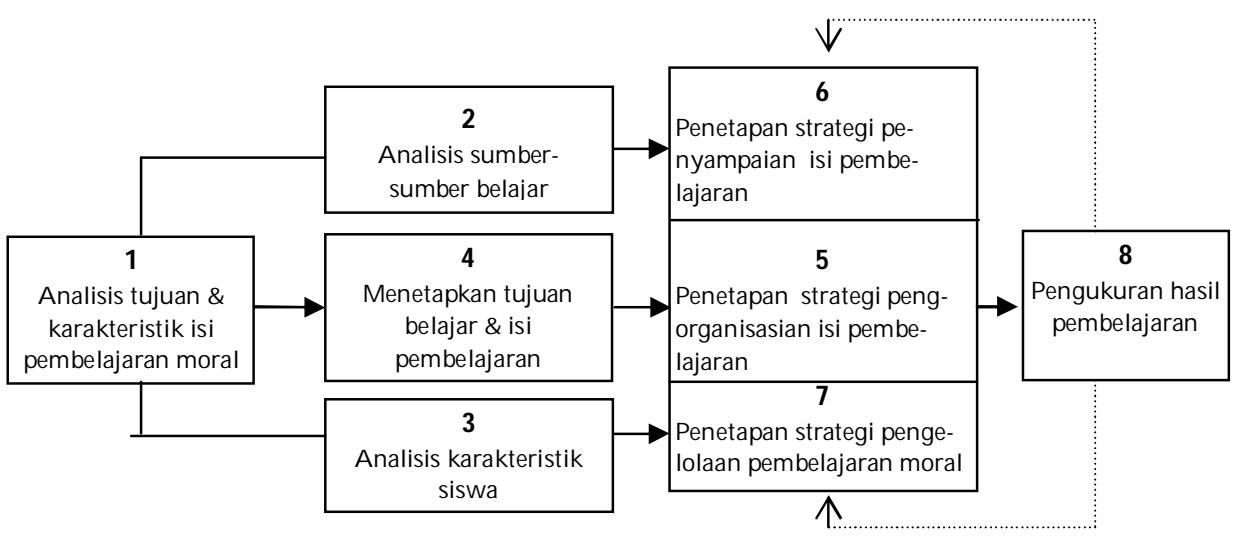

Diagram 2: Model Desain Pembelajaran (Adaptasi dari Degeng, 1991) 
Diagram 2 secara jelas menunjukkan bahwa analisis karakteristik siswa dilakukan setelah perancang pembelajaran mengidentifikasi tujuan pembelajaran yang ingin dicapai. Juga ditunjukkan bahwa hasil analisis karakteristik siswa selanjutnya dijadikan pijakan kerja dalam memilih, menetapkan, dan mengembangkan strategi pengelolaan pembelajaran. Dengan konteks seperti ini, menjadi semakin jelas perlunya dilakukan penelitian karakteristik siswa yang berkaitan dengan kefektifan pembelajaran agar dapat dipakai sebagai dasar bagi para ilmuwan dan teknolog pembelajaran serta para guru dalam mendesain programprogram pembelajaran.

Jika dalam menyampaikan materi pelajaran guru kurang memperhatikan karakteristik siswa dan ciri-ciri kepribadian siswa tidak dijadikan pijakan dalam pembelajaran, siswa akan mengalamai kesulitan memahami materi pelajaran. Mereka merasa bosan, bahkan timbul kebencian terhadap materi pelajaran yang diajarkan oleh guru. Kondisi demikian sebagai penyebab rendahnya kualitas dan kuantitas proses serta hasil belajar yang telah diprogramkan. Upaya apa pun yang dipilih dan dilakukan oleh guru dan perancang pembelajaran jika tidak bertumpu pada karakteristik perseorangan siswa sebagai subjek belajar, maka pembelajaran yang dikembangkan tidak akan bermakna bagi siswa.

Karakteristik siswa yang dapat diidentifikasi sebagai faktor yang amat berpengaruh terhadap proses dan hasil belajar adalah kecerdasan, kemam- puan awal, gaya kognitif, gaya belajar, motivasi, dan faktor sosial-budaya. Informasi tentang tingkat perkembangan kecerdasan siswa amat diperlukan sebagai pijakan dalam memilih komponen-komponen pembelajaran, seperti tujuan pembelajaran, materi, media, strategi pembelajaran dan evaluasi (Gardner, 1993; Amstrong, 1994). Menurut Suparno (2001), siswa yang berada pada tahap pemikiran operasional konkret sudah memiliki kecakapan berpikir logis, tetapi hanya melalui benda-benda konkret sehingga semua komponen pembelajaran perlu disesuaikan dengan kemampuan tersebut. Sebaliknya, mereka yang sudah berada pada tahap operasi formal sudah mampu berpikir abstrak dan logis dengan menggunakan pola berpikir "kemungkinan". Mereka sudah dapat berpikir ilmiah, baik deduktif maupun induktif, serta mampu menarik kesimpulan, menafsirkan dan mengembangkan hipotesis. Oleh sebab itu, komponen-komponen pembelajaran sudah dapat dirancang sedemikian rupa untuk diarahkan pada kemampuan tersebut.

Informasi tentang kemampuan awal yang sudah dimiliki siswa (Degeng, 1991; Dochy, 2002) amat diperlukan guru sebagai pijakan dalam mengorganisasi dan menyampaikan materi pelajaran. Bila guru mengajarkan materi pelajaran yang sudah dipahami siswa, pembelajaran tidak efektif, tidak efisien dan kurang memiliki daya tarik. Siswa akan merasa bosan atau jenuh sehingga suasana belajar menjadi terganggu. Sebaliknya, jika guru mengajarkan materi 
pelajaran di luar atau lebih tinggi dari kemampuan siswa, atau siswa belum menguasai pengetahuan prasyaratnya, maka siswa akan menjadi bingung, stres, dan sulit memahami materi pelajaran.

Informasi mengenai kemampuan awal siswa juga diperlukan dalam mengembangkan media dan sumbersumber belajar. Penulisan buku teks atau bahan ajar, apakah perlu menggunakan pengetahuan analogi untuk memahami suatu konsep? Apakah diperlukan mnemonik atau jembatan keledai untuk menghapalkan suatu informasi? Atau, apakah perlu dikaitkan antara pengetahuan yang sedang dipelajari dengan pengetahuan-pengetahuan tingkat yang lebih rendah, dan sebagainya.

Informasi mengenai gaya kognitif siswa bermanfaat untuk keperluan mengembangkan strategi pembelajaran (Riding, 2002; Riding dan Rayner, 2002), serta membangun teori-teori tentang bagaimana mengembangkan dan memproduksi bahan-bahan ajar, khususnya yang berkaitan dengan cara mengorganisasi materi pembelajaran. Siswa dengan gaya kognitif field-independent lebih memiliki kemampuan untuk menstruktur atau mengorganisasi materi pelajaran secara mandiri. Siswa dengan gaya kognitif field-dependent akan lebih mudah belajar jika materi pelajaran sudah distruktur lebih dahulu (Entwistle, 1981, Degeng, 1991). Informasi mengenai gaya kognitif ini juga penting bagi penulisan bahan ajar khususnya dalam memberi petunjuk apakah ketika menyusun bahan ajar perlu diser- tai dengan kerangka isi atau advance organizer, atau epitome, atau skema yang memuat seluruh materi pelajaran.

Informasi mengenai motivasi belajar siswa (Handoko, 1992) juga akan sangat diperlukan oleh guru dalam mengembangkan strategi pembelajaran, khususnya yang berkaitan dengan strategi penyampaian materi pelajaran serta strategi pengelolaan motivasional. Informasi mengenai gaya belajar siswa (Entwistle, 1981) amat diperlukan dalam mengembangkan strategi penyampaian materi pelajaran serta dalam mengembangkan media dan sumber-sumber belajar. Produksi media pembelajaran, misalnya, memerlukan informasi mengenai bagaimana kecenderungan siswa dengan gaya belajar visual, auditorial, dan kinestetik. Dengan mengetahui kecenderungan-kecenderungan gaya belajar tersebut, strategi dan media pembelajaran yang akan diproduksi dapat disesuaikan sehingga mampu melayani masing-masing gaya belajar siswa.

Demikian pula dengan faktor sosial-budaya (Brameld, 1997; Pannen dalam Padmo, 2003) adalah penting diketahui oleh para guru untuk dijadikan pijakan dalam menyampaikan materi pembelajaran serta mengelola kegiatan pembelajaran. Informasi ini juga urgen bagi para pengembang media dan sumber-sumber belajar agar strategi dan media-media pembelajaran yang digunakan dalam pembelajaran selaras dengan kondisi sosial budaya di mana siswa berada.

Informasi mengenai karakteristik siswa sebagaimana diuraikan di atas 
hingga kini belum banyak tersedia sehingga kesahihan teori-teori dan prinsip-prinsip pembelajaran yang dikembangkan di Indonesia masih rendah. Tulisan ini secara khusus dimaksudkan untuk menyediakan informasi tersebut, agar dapat dijadikan pijakan bagi para guru, peneliti dan perancang pembelajaran sehingga prinsipprinsip dan praktek-praktek pembelajaran dapat dikembangkan sesuai dengan karakteristik siswa.

\section{KESIMPULAN}

Masih banyak praktik pembelajaran yang kurang memperhatikan karakteristik siswa. Kegiatan pembelajaran semata-mata hanya untuk menyelesaikan program-program yang tertuang di dalam kurikulum. Ciri-ciri kepribadian siswa tidak dijadikan pijakan dalam pembelajaran. Akibatnya, siswa mengalamai kesulitan belajar, mereka merasa stres, bahkan timbul kebencian terhadap pelajaran yang dipelajarinya. Kondisi demikian sebagai penyebab rendahnya kualitas dan kuantitas proses serta hasil belajar siswa.

Gunameningkatkan kualitas pembelajaran, para peneliti di bidang pembelajaran serta para perancang pembelajaran perlu menjadikan karakteristik siswa dan budayanya sebagai pijakan dalam mengembangkan prinsip-prinsip dan program-program pembelajaran. Sebab, upaya apapun yang dipilih dan dilakukan oleh guru dan perancang pembelajaran jika tidak bertumpu pada karakteristik perseorangan siswa sebagai subjek belajar, pembelajaran yang dikembang- kannya tidak akan bermakna bagi siswa.

Kajian ini berpijak pada asumsi bahwa (1) perbaikan kualitas pembelajaran diawali dari desain pembelajaran. Perencanaan pembelajaran dapat dijadikan titik awal upaya perbaikan kualitas pembelajaran. Ini berarti bahwa perbaikan kualitas pembelajaran haruslah diawali dari perbaikan kualitas desain pembelajaran; (2) desain pembelajaran diacukan kepada si belajar (siswa) secara perseorangan dan/atau kelompok. Siswa haruslah dijadikan titik acuan dalam mendesain pembelajaran. Tindakan atau perilaku belajar memang dapat dipengaruhi, tetapi tindakan atau perilaku belajar akan tetap berjalan sesuai dengan karakteristik siswa.

Berbagai penelitian amat penting dilakukan untuk menemukan buktibukti empirik mengenai karakteristik siswa yang berkaitan dengan upaya menetapkan metode pembelajaran guna mencapai hasil pembelajaran yang optimal. Informasi ini sangat dibutuhkan oleh para guru, peneliti dan teknolog pembelajaran maupun ilmuwan pembelajaran sebagai: (1) landasan pijak pengembangan teori-teori pembelajaran yang sesuai dengan kondisi siswa dan sosial-budayanya; (2) landasan pijak dalam melakukan penelitian dan pengembangan program-program pembelajaran; (3) landasan pijak bagi perancang untuk memproduksi bahan-bahan pembelajaran, seperti buku-buku teks serta media dan sumber-sumber belajar lainnya. 


\section{UCAPAN TERIMA KASIH}

Terima kasih diucapkan kepada tim Redaktur dan staf Jurnal Cakrawala Pendidikan Universitas Negeri Yogyakarta yang telah memberikan kesempatan kepada penulis untuk mempublikasikan artikel ini. Mudahmudahan tulisan ini dapat menambah wawasan bagi para pembaca akan pentingnya karakteristik siswa sebagai pijakan penelitian-penelitian pembelajaran serta upaya mengembangkan program-program pembelajaran menuju pada peningkatan kualitas pembelajaran.

\section{DAFTAR PUSTAKA}

Amstrong, T. 1994. Multiple Intelligences in the Classroom. Alexandria: ASCD

Anitah. 1996. "Penerapan Teori Elaborasi untuk Meningkatkan Perolehan Belajar Teori Musik Dasar Mahasiswa PGSD". Tesis. tidak dipublikasikan. Malang: PPs. UM.

Ardhana, W. 1999. Sambutan Promotor. Malang: Pada Ujian Akhir Drs. Binsar Panjaitan, M.Pd., Universitas Negeri Malang.

Atmadi, A. dan Setiyaningsih, Y. 2004. Transformasi Pendidikan Memasuki Milenium Ketiga. Yogyakarta: Kanisius dan USD.

Brameld, T. 1997. Cultural Foundations of Education. (Penerbit tidak diketahui).
Degeng, N.S. 1989. Ilmu Pengajaran Taksonomi Variabel. Jakarta: Depdikbud Dirjen Dikti.

1998. Interactive Effects of Instructional Strategy and Leaner Characteristics on Learning Effectiveness and Appeal. Jakarta: Urge Batch II.

. 1991. Karakteristik Belajar Mahasiswa Berbagai Perguruan Tinggi di Indonesia. Jakarta: Depdikbud Dirjen Dikti Proyek Pengembangan Pusat Fasilitas Bersama Antar Universitas/UC

Dewanti, S. 2009. "Keefektifan Perpaduan PCL dan Pelatihan Metakognitif dalam Meningkatkan Kemampuan Memecahkan Masalah Matematika". Jurnal Penelitian dan Evaluasi Pendidikan, Vol. 13, No. 1, hal. 21-37.

Djohan. 2009. “Kemampuan Musikalitas sebagai Sarana Pengembangan Keteramplan Sosial". Jurnal Penelitian dan Evaluasi Pendidikan, Vol. 13, No. 1, hal. 111-126

Dochy, F.J.R.C. 2002. The Use of Prior Knowledge State Tests and Knowledge Profiles. (penerbit tidak diketahui)

Entwistle, N. 1981. Styles of Learning and Teaching. New York: John Wiley \& Son. 
Gardner, H. 1993. Multiple Intelligences: The Theory in Practice. New York: Basic Books.

Handoko, M. 1992. Motivasi Daya Penggerak Tingkah Laku. Yogyakarta: Penerbit Kanisius.

Haryanto, B. 2009. "Efikasi Diri, Kualitas Pengajaran, Sikap Positif, dan Kenerja Akademis Mahasiwa". Jurnal Ilmu Pendidikan. Vol. 16, No. 3, hal. 152-161.

Indarini D. P. 2009. "Peningkatan Aktivitas dan Pemahaman Siswa dalam Pembelajaran Kimia melalui Pendekatan Kontekstual". Jurnal Ilmu Pendidikan, Vol. 16, No. 3, hal. 172-177.

Lusiana. 1992."Pengaruh Interaktif antara Penggunaan Strategi Penataan Isi Matakuliah dan Gaya Kognitif Mahasiswa terhadap Perolehan Belajar". Tesis, tidak dipublikasikan). Malang: PPs IKIP Malang.

Moll, L. C. (ed). 1994. Vygotsky and Education: Instructional Implications and Applications of Sociohistorycal Psychology. Cambrige: University Press.

Padmo, D. 2003. Faktor-faktor perancangan Pembelajaran MIPA Berbasis Budaya, (dalam Dewi Padmo, dkk.). Teknologi Pembelajaran. Jakarta: UT, Pustekom, IPTPI.
Rahmadona, S. 2008. "Pengembangan Multimedia Pembelajaran untuk Melatih Kecerdasan Majemuk Pada Anak Usia Dini". Tesis, tidak dipublikasikan. Yogyakarta: PPs UNY.

Reigeluth, C.M. 1983. Instructional Design: What is It and Why is It? Dalam C.M. Reigeluth (Ed.), Instructional Design Theories and Models: an Overview of Their Current Status. Hillsdale, N.J.: Lawrence Erlbaum Associates.

Riding, R. 2002. School Learning and Cognitive Style. London: David Fulton Publishers.

Riding, R., \& Rayner, S. 2002. Cognitive Styles and Learning Strategies. London: David Fulton Publishers.

Seels, B. B. \& Richey, R. 1994. Instructional Technology: the Definition and Domains of The Field. Washington D. C.: AECT.

Siskandar. 2009. "Keefektifan Pendekatan Cooperative Learning dalam Meningkatkan Aktivitas dan Hasil Belajar Mahasiswa". Jurnal Ilmu Pendidikan, Vol.16, No. 3, hal. 178-185.

Suhardjono. 1990. Pengaruh Gaya Kognitif dan Perancangan Pengajaran Berdasar Component Display Theory terhadap Perolehan Belajar, Retensi dan Sikap. (Disertasi tidak dipublikasika). Malang: FPSIKIP Malang. 
Suparmi. 2010. “Pengembangan Multimedia Pembelajaran Sosiologi untuk Meningkatkan Kemampuan Sosial Siswa di SMA Kelas XI". Tesis, tidak dipublikasikan, PPS-UNY.

Suparno, P. 2001. Teori Perkembangan Kognitif Jean Piaget. Yogyakarta: Penerbit Kanisius.

Triyono, M. B. 2008. “Pengaruh Strategi Pembelajaran dan Kemampuan Analitik terhadap Keterampilan Pneumatik Mahasiswa Teknik Mesin UNY". Jurnal Penelitian dan Evaluasi Pendidikan, Vol. 1, No. XI, hal.1-17. 